\title{
Trends in the availability of the vulture-toxic drug, diclofenac, and other NSAIDs in South Asia, as revealed by covert pharmacy surveys.
}

\begin{tabular}{|c|c|}
\hline Journal: & Bird Conservation International \\
\hline Manuscript ID & BCI-MP-2020-0003.R2 \\
\hline Manuscript Type: & Research Article \\
\hline $\begin{array}{r}\text { Date Submitted by the } \\
\text { Author: }\end{array}$ & 03-Jul-2020 \\
\hline Complete List of Authors: & $\begin{array}{l}\text { Galligan, Toby; Royal Society for the Protection of Birds, Centre for } \\
\text { Conservation Science } \\
\text { Mallord, John; Royal Society for the Protection of Birds, Centre for } \\
\text { Conservation Science } \\
\text { Prakash, Vibhu; Bombay Natural History Society, Vulture Conservation } \\
\text { Programme } \\
\text { Bhusal, Krishna; Bird Conservation Nepal, Bird Conservation Nepal } \\
\text { Alam, ABM ; IUCN, Bangladesh Country Office } \\
\text { Ranade, Sachin; Bombay Natural History Society, Vulture Conservation } \\
\text { Programme } \\
\text { Prakash, Nikita; Bombay Natural History Society, Hornbill House, S.B. } \\
\text { Singh Road } \\
\text { Shringarpure, Rohan; Bombay Natural History Society, Hornbill House, } \\
\text { S.B. Singh Road } \\
\text { Kartik, Shastri; Bombay Natural History Society, Vulture Conservation } \\
\text { Programme } \\
\text { Dube, Alka; Bombay Natural History Society, Vulture Conservation } \\
\text { Programme } \\
\text { Dave, Ruchi; Bombay Natural History Society, Vulture Conservation } \\
\text { programme } \\
\text { Kumar, Yogesh; Bombay Natural History Society, Vulture Conservation } \\
\text { Programme } \\
\text { Anthony, Fergus; Bombay Natural History Society, Vulture Conservation } \\
\text { Programme } \\
\text { Chaudhary, Ishwari; Bird Conservation Nepal, na } \\
\text { Chapagain, Devendra; Bird Conservation Nepal, Conservation } \\
\text { Joshi, Ankit; Bird Conservation Nepal, Bird Conservation Nepal } \\
\text { Paudel, Khadananda; Bird Conservation Nepal, na } \\
\text { Kabir, Tarik; IUCN, Bangladesh Country Office } \\
\text { Ahmed, Sakib; IUCN, Bangladesh Country Office } \\
\text { Azmiri, Kazi; IUCN, Bangladesh Country Office } \\
\text { Cuthbert, Richard; Royal Society for the Protection of Birds, RSPB } \\
\text { Bowden, Christopher; RSPB, Conservation } \\
\text { Green, Rhys; University of Cambridge, Zoology Department } \\
\end{array}$ \\
\hline Keywords: & $\begin{array}{l}\text { Non-steroidal anti-inflammatory drugs, }<\text { i }>\text { Gyps }</ \text { i }>\text {, India, Nepal, } \\
\text { Bangladesh }\end{array}$ \\
\hline Abstract: & $\begin{array}{l}\text { The catastrophic declines of three species of Critically Endangered Gyps } \\
\text { vultures in South Asia were caused by unintentional poisoning by the } \\
\text { non-steroidal anti-inflammatory drug (NSAID) diclofenac. Despite a ban } \\
\text { on its veterinary use in } 2006 \text { (India, Nepal, Pakistan) and } 2010 \\
\text { (Bangladesh), residues of diclofenac have continued to be found in cattle } \\
\text { carcasses and in dead wild vultures. Another NSAID, meloxicam, has } \\
\text { been shown to be safe to vultures. From } 2012 \text { to 2018, we undertook }\end{array}$ \\
\hline
\end{tabular}


covert surveys of pharmacies in India, Nepal and Bangladesh to investigate the availability and prevalence of NSAIDs for the treatment of livestock. The purpose of the study was to establish whether diclofenac continued to be sold for veterinary use, whether the availability of meloxicam had increased and to determine what other veterinary NSAIDs were available. The availability of diclofenac declined in all three countries, virtually disappearing from pharmacies in Nepal and Bangladesh, highlighting the advances made in these two countries to reduce this threat to vultures. In India, diclofenac still accounted for $10-46 \%$ of all NSAIDs offered for sale for livestock treatment in 2017, suggesting weak enforcement of existing regulations and a continued high risk to vultures. Availability of meloxicam increased in all countries, and was the most common veterinary NSAID in Nepal (89.9\% in 2017). Although the most widely available NSAID in India in 2017, meloxicam accounted for only $32 \%$ of products offered for sale. In Bangladesh, meloxicam was less commonly available than the vulture-toxic NSAID ketoprofen (28\% and 66\%, respectively, in 2018), despite the partial government ban on ketoprofen in 2016. Eleven different NSAIDs were recorded, several of which are known or suspected to be toxic to vultures. Conservation priorities should include awareness raising, stricter implementation of current bans, bans on other vulture-toxic veterinary NSAIDs, especially aceclofenac and nimesulide, and safetytesting of other NSAIDs on Gyps vultures to identify safe and toxic drugs.

\section{SCHOLARONE" Manuscripts}



Trends in the availability of the vulture-toxic drug, diclofenac, and other

2 NSAIDs in South Asia, as revealed by covert pharmacy surveys.

3

4

TOBY H. GALLIGAN,$^{1+}$, JOHN W. MALLORD ${ }^{1 *}$, VIBHU M. PRAKASH ${ }^{2}$, KRISHNA P. BHUSAL ${ }^{3}$, A.B.M. SAROWAR ALAM ${ }^{4}$, FERGUS M. ANTHONY², RUCHI DAVE², ALKA DUBE², SHASTRI KARTIK², YOGESH KUMAR ${ }^{2}$, NIKITA PRAKASH ${ }^{2}$, SACHIN RANADE², ROHAN SHRINGAPURE², DEVENDRA CHAPAGAIN ${ }^{3}$, ISHWARY P. CHAUDHARY ${ }^{3}$, ANKIT B. JOSHI ${ }^{3}$, KHADANANDA PAUDEL 3 , TARIK KABIR ${ }^{4}$, SAKIB AHMED ${ }^{4}$, KAZI Z. AZMIRI ${ }^{4}$, RICHARD J. CUTHBERT ${ }^{1 \neq}$, CHRISTOPHER G.R. BOWDEN ${ }^{5}$ and RHYS E. GREEN ${ }^{1,6}$

${ }^{1}$ RSPB Centre for Conservation Science, The Lodge, Sandy, Bedfordshire, SG19 2DL, UK

2 Bombay Natural History Society, Hornbill House, Mumbai, 400023, India

${ }^{3}$ Bird Conservation Nepal, PO Box 12465, Lazimpat, Kathmandu, Nepal

${ }^{4}$ IUCN Bangladesh Country Office, House B-138, Lane 22, Mohakhali DOHS, Dhaka 1206, Bangladesh ${ }^{5}$ RSPB, Apartment 201, Sobha Jade, $2^{\text {nd }}$ Floor, Block B, Jakkur, Yelahanka Hobli, Bangalore, North Taluk, Karnataka, 560 064, India

${ }^{6}$ Conservation Science Group, Department of Zoology, University of Cambridge, Downing Street, CB2 3EJ, UK

* Corresponding author: john.mallord@rspb.org.uk

${ }^{+}$Current address: 6 Itawara Place, Bridgewater, South Australia, Australia, 5155

‡ Current address: World Land Trust, Blyth House, Bridge Street, Halesworth, Suffolk, IP19 8AB, UK

Keywords: Non-steroidal anti-inflammatory drugs, Gyps, India, Nepal, Bangladesh

Running head: Availability of NSAIDs in South Asia 


\section{Summary}

The catastrophic declines of three species of Critically Endangered Gyps vultures in South Asia were caused by unintentional poisoning by the non-steroidal anti-inflammatory drug (NSAID) diclofenac. Despite a ban on its veterinary use in 2006 (India, Nepal, Pakistan) and 2010 (Bangladesh), residues of diclofenac have continued to be found in cattle carcasses and in dead wild vultures. Another NSAID, meloxicam, has been shown to be safe to vultures. From 2012 to 2018, we undertook covert surveys of pharmacies in India, Nepal and Bangladesh to investigate the availability and prevalence of NSAIDs for the treatment of livestock. The purpose of the study was to establish whether diclofenac continued to be sold for veterinary use, whether the availability of meloxicam had increased and to determine what other veterinary NSAIDs were available. The availability of diclofenac declined in all three countries, virtually disappearing from pharmacies in Nepal and Bangladesh, highlighting the advances made in these two countries to reduce this threat to vultures. In India, diclofenac still accounted for $10-46 \%$ of all NSAIDs offered for sale for livestock treatment in 2017, suggesting weak enforcement of existing regulations and a continued high risk to vultures. Availability of meloxicam increased in all countries, and was the most common veterinary NSAID in Nepal (89.9\% in 2017). Although the most widely available NSAID in India in 2017, meloxicam accounted for only $32 \%$ of products offered for sale. In Bangladesh, meloxicam was less commonly available than the vulture-toxic NSAID ketoprofen ( $28 \%$ and $66 \%$, respectively, in 2018), despite the partial government ban on ketoprofen in 2016. Eleven different NSAIDs were recorded, several of which are known or suspected to be toxic to vultures. Conservation priorities should include awareness raising, stricter implementation of current bans, bans on other vulture-toxic veterinary NSAIDs, especially aceclofenac and nimesulide, and safety-testing of other NSAIDs on Gyps vultures to identify safe and toxic drugs. 


\section{Introduction}

The non-steroidal anti-inflammatory drug (NSAID) diclofenac is nephrotoxic to Gyps vultures (Oaks et al. 2004, Swan et al. 2006a). The widespread use of diclofenac in South Asia during the 1990s and 2000 s to provide palliative care to dying cattle caused catastrophic declines in populations of the three resident Gyps vulture species endemic to the region, White-rumped G. bengalensis, Indian $G$. indicus and Slender-billed G. tenuirostris Vultures. Vultures were exposed to sufficient levels of contaminated food to cause the observed population declines when they fed upon carcasses of cattle which had been treated with diclofenac shortly before their death (Green et al. 2004, 2007). To save vultures from extinction, the Governments of India, Nepal and Pakistan banned the manufacture of veterinary formulations of diclofenac in 2006, followed by the Government of Bangladesh in 2010.

In India, repeated road transect surveys of vultures across much of their former range have shown at least a slowing of declines since the ban and a possible partial recovery in the population of Whiterumped Vulture (Prakash et al. 2017). In addition, both the prevalence and concentration of diclofenac in cattle carcasses sampled throughout the same area declined between 2006 and 2009 such that the estimated vulture death rate per meal decreased by about two-thirds (Cuthbert et al. 2014). However, up to that time, the ban had not eliminated diclofenac from vulture food in India or allowed vulture populations to recover strongly. Furthermore, the proportion of vultures found dead in the wild in India with diclofenac residues showed only a slight and non-significant decline after the ban (Cuthbert et al. 2016).

Cuthbert et al. (2011) surveyed pharmacies selling veterinary drugs in India and found that many were stocking and selling human formulations of diclofenac for illegal use in cattle. This misuse was 
made more practical by the manufacture and distribution to veterinary pharmacies, by some Indian pharmaceutical companies, of human formulations of diclofenac in large vials containing enough of the drug to dose cattle. This explained why many cattle carcasses were still found with diclofenac residues (Cuthbert et al. 2014), dead vultures were still found with diclofenac residues and visceral gout (Cuthbert et al. 2015), and vulture populations had not recovered strongly (Prakash et al. 2017). The prevalence of diclofenac in cattle carcasses before and after bans in Bangladesh, Nepal and Pakistan was not measured. However, population surveys of vultures in Nepal and Pakistan have shown a reversal of declines since the bans on veterinary diclofenac (Chaudhry et al. 2012, Galligan et al. 2019).

In 2015 , the Government of India strengthened its regulations on diclofenac by banning the manufacture of human formulations in vials larger than a single human dose ( $3 \mathrm{ml})$. Two Indian pharmaceutical companies immediately challenged the ban, but it was upheld in the High Court of Madras in 2017. This strengthening of the ban may make diclofenac use in cattle less practical and expensive, because multiple small vials would need to be used, and further reduce the illegal use of human diclofenac formulations in cattle in India, though the legal challenge to the ban on the use of larger vials would have delayed this effect. Given the influence of India's pharmaceutical industry in the region and the far-ranging movements of vultures, this enhancement of the ban is expected to have a positive effect on vultures in neighbouring countries as well.

Another NSAID, meloxicam, is the only veterinary NSAID known not to be toxic to Gyps vultures at doses likely to be used in veterinary practice (Swan et al. 2006b). Conservationists and governments in South Asia have been promoting the use of meloxicam while discouraging the use of diclofenac. In India, the prevalence of meloxicam in cattle carcasses increased by nearly half between 2006 and 2009, whilst the prevalence of diclofenac decreased (Cuthbert et al. 2014a). In addition, the prevalence of diclofenac in cattle carcasses in India decreased most in regions where meloxicam 
prevalence increased most (Cuthbert et al. 2014b). Counteracting this positive trend, there are many other NSAIDs available for use on cattle in South Asia, including aceclofenac, which metabolises into diclofenac in cattle (Galligan et al. 2016), ketoprofen and carprofen which are toxic to Gyps vultures (Naidoo et al. 2010, 2018), and nimesulide and flunixin, which have been found in dead wild Gyps vultures with visceral gout and are therefore probably vulture-toxic (Zorrilla et al. 2014, Cuthbert et al. 2015).

In this study, we undertook covert (undercover) surveys of pharmacies selling veterinary drugs in India, Nepal and Bangladesh to determine which NSAIDs are being sold for use in cattle. The use of covert surveys was necessary as the sale of diclofenac for veterinary purposes is illegal in all three countries and availability would otherwise have been significantly under-reported from overt surveys (Cuthbert et al. 2011). Our aims were to assess (1) how effective the ban on veterinary diclofenac has been, (2) whether the only known vulture-safe drug, meloxicam, has taken over from diclofenac as a preferred drug, and (3) what other NSAIDs are currently available.

\section{Methods}

Repeated covert surveys of pharmacies were carried out in eight regions of India, three regions of Nepal, and three regions in Bangladesh. Whereas the same regions were consistently surveyed in India and Nepal, the first survey in Bangladesh covered the whole country, while the second and third surveys were conducted in the country's two provisional Vulture Safe Zones (pVSZ) centred on the Sylhet and Khulna Divisions (administrative regions). The latter two surveys in Bangladesh, therefore, constituted repeat coverage of the same regions. The survey was based upon sampling of settlements, which were towns, villages or clusters of small villages. Settlements were selected at random within each region. Data were collected from just one pharmacy in each settlement visited, thus avoiding possible pseudoreplication arising from likely patterns among pharmacies within 
settlements. The name, address and sometimes the geographical coordinates of each pharmacy was recorded by the survey team from the vehicle on the first survey and used to locate the same pharmacy in future years. In India and Bangladesh, surveyors were employees of the organisations undertaking the surveys (BNHS and IUCN Bangladesh, respectively), whereas in Nepal, a local man was paid to visit a pharmacy and purchase medicine for an injured cow.

Methods varied between countries. In India, a member of the survey team asked the pharmacist for "a painkiller for an injured cow". However, in surveys in 2012 and 2013 in Jharkhand, Uttarakhand and Uttar Pradesh, surveyors specifically asked for, or a had a prescription, for diclofenac. Diclofenac was offered more frequently when the drug was specifically requested (44.2\% of pharmacies), compared to when the standard method was followed $\left(15.6 \%, \chi^{2}{ }_{1}=42.38, P<0.0001\right)$. Therefore, surveys that did not follow the standard method have been excluded from the modelling of trends over time. In Nepal, a prescription written by a veterinarian for one $30 \mathrm{ml}$ vial of diclofenac and five tablets of deworming medication was presented to the pharmacist. In both India and Nepal, the first drug offered by the pharmacist was bought, regardless of what had been requested, although it was often the case that no drug was offered, because the pharmacist either did not stock, or had run out of, this type of drug. In Nepal, drugs intended for animals and humans are often sold in separate shops; therefore, surveys were conducted in both 'Animal' and 'Human' pharmacies, but it was always made clear that the drug purchased was intended for use on cattle. In Bangladesh, surveyors asked to see all NSAIDs in stock in each pharmacy. Data were collected from the packaging of the purchased (and in Bangladesh, stocked) drugs, including brand name, name and concentration of the active ingredient(s), vial size and the manufacturer's name and address.

\section{Statistical analysis}

Changes over time in the first NSAID offered for sale in India and Nepal were tested by fitting logistic regression models. Whether or not an NSAID was the first drug offered and subsequently bought 
during a pharmacy visit was the binary dependent variable with binomial error and a log link function, and was modelled in relation to the calendar year as a continuous variable. The same modelling approach was used to study trends in the availability of individual NSAIDs, but only including data from pharmacy visits in which an NSAID of some kind was offered. Interaction terms between regions and year were not fitted and data for each region of India and Nepal were modelled separately. After inspecting the data, we included the quadratic effect of calendar year when modelling trends in sales of meloxicam in the Western Terai region of Nepal. We report the slope of the fitted logistic regression $(b)$ from these analyses and tested the statistical significance of its difference from zero using its asymptotic standard error and a $t$-test. This coefficient represents the modelled mean change per year in the logarithm of the odds of a drug being offered under a model in which the log odds is assumed to be a linear function of year. Negative $b$ values indicate declines over time and positive values represent increases. Where data were only available from two surveys, i.e. the repeat survey of the two pVSZs in Bangladesh, we performed chi-square tests of association to investigate differences between surveys in the relative proportions of selected NSAIDs (proportion of all NSAIDs stocked that were meloxicam versus ketoprofen). The proportion of diclofenac offered in vials of different sizes before and after the ban on vials $>3 \mathrm{ml}$ was also investigated with a chi-squared test of association.

Human ethics

This study involved interactions with people, including staff of pharmacies and the local men recruited to collect data. The welfare of these participants was considered. Pharmacy staff were approached in their shops, open to the public, therefore, our interactions occurred in the public sphere, where a person accepts the responsibility of their actions and those actions can be publicly observed (Spicker 2011). Thus, pharmacy staff waive the rights normally given to participants in research (e.g. consent, withdraw, privacy; Spicker 2011), permitting covert interactions. Deceit to elicit a sale of diclofenac (i.e. asking for a painkiller for an animal and using a mock prescription) was 
needed to uncover illegal behaviour. Covert interactions and deceit are important tools for data collection in conservation science, particularly when investigating illegal behaviour. Both are justified because obtaining accurate data would otherwise not be possible. Further, illegal behaviour is a concern of the public and public rights take priority over individual rights in such circumstances (Spicker 2011). In this case, the conservation of vultures and the ecosystem services that they provide are concerns of the public, and the sale of diclofenac and the killing of vultures in Bangladesh, India and Nepal are crimes and thereby concerns of the public.

In India and Bangladesh, surveyors were members of conservation organisations managing the surveys and, therefore, understood the reasons behind the surveys. In Nepal, where local men were asked to collect data, they were given full information regarding the purpose of the survey. Thus, fully appraised, they were able to make an informed decision whether to participate or not, and were also given the right to withdraw at any time. No data were collected on the local men.

Our study was sanctioned by state and national agencies responsible for wildlife protection and drug control through the respective countries' Government-endorsed Vulture Conservation Action Plans. A summary of our data was sent to the relevant authorities, although offending individuals were not reported, and are not identified in this paper.

\section{Results}

India

A total of 1452 covert pharmacy visits were made in all regions of India between 2012 and 2017, during which an NSAID was bought on 1129 (77.8\%). No drug was offered on $15.0 \%$ of all visits ( $N=$ 217). Of these cases, pharmacy staff refused to sell any drug on 35 of visits, most often $(\mathrm{N}=25)$ because a prescription was not provided. An alternative drug, rather than an NSAID, was offered on 
$7.3 \%$ of visits $(N=106)$ and this was usually an antibiotic $(N=70)$. The proportion of pharmacies in which an NSAID was bought varied between regions (range, 54\% (Central Gujarat) to 98\% (Haryana pVSZ)) and declined significantly over the course of the study (effect of year, $b=-0.392 \pm 0.05, t=$ 8.34, $P<0.0001)$. Of those pharmacies that did not offer any NSAID, $119(37 \%)$ offered another type of drug. Where the data were recorded ( $n=1108$ visits), $78 \%$ of all NSAIDs were sold in injectable form, rather than a bolus, but the proportion of injectable forms was higher for diclofenac (97\%).

Meloxicam, diclofenac, nimesulide and piroxicam accounted for the majority of NSAIDs sold (93\%), the remainder consisting of six other drugs: aceclofenac, metamizole (tradename Analgin), ketoprofen, mefenamic acid, phenylbutazone and tolfenamic acid (Table 1). In those regions in which surveyors asked explicitly for diclofenac (Jharkhand, Uttarakhand and Uttar Pradesh), there was a significant reduction in the proportion of NSAIDs sold that were diclofenac between 2012 (53.8\%) and $2013\left(14 \%, \chi^{2}{ }_{1}=22.79, P<0.0001\right)$. Excluding those region/year combinations in which the standard survey method was not used (see Methods), there were significant declines in the proportion of visits at which diclofenac was offered in both Assam and Madhya Pradesh, but there was a significant increase in southern Gujarat (Fig. 1a, Table 2). Diclofenac was bought in all five regions during the final survey in 2017 (10-46\% of all NSAIDs sold). Across all surveys in India, only in Assam in 2016 was diclofenac not offered for sale, from a high of 30\% of NSAIDs bought in 2012 (Table 1). Diclofenac was either the most frequent or joint most frequently offered drug in both regions of Gujarat in 2017; and reached 20\% of sales in Madhya Pradesh and Uttar Pradesh. Diclofenac was sold in various vial sizes $(1,2,3,9,15,30$ and $50 \mathrm{ml}$ ) and manufactured in India (46 companies overall, 15 companies in 2017). In 2012-2015, before the ban in 2016 on the production of large vials $(>3 \mathrm{ml})$ of diclofenac for human medicine, $92 \%(n=224)$ of vials sold were $>3 \mathrm{ml}$, but this proportion significantly dropped to $54 \%(n=76)$ after the ban $\left(2016-2017 ; \chi^{2}{ }_{1}=53.80, P<\right.$ $0.0001)$. Of those large vials sold after the government ban on large vials $(n=41)$, four $(10 \%)$ had a manufacturing date that post-dated the ban, the rest consisted of older stock. 
Meloxicam was the most commonly offered drug overall ( $36 \%$ of NSAIDs bought). There were significant increases in the proportion of visits where this drug was offered in Madhya Pradesh and Uttar Pradesh, but little evidence of change in Assam, Central Gujarat and Southern Gujarat (Table 2;

Fig. 1b). In 2017, meloxicam constituted $15-46 \%$ of sales in the five regions surveyed using the standard method although it was more prevalent in other regions earlier in the study (Table 1). It accounted for the highest (or joint highest) sales in Southern Gujarat, Madhya Pradesh and Uttar

Pradesh in 2017. There were near- significant increases in the proportion of visits where nimesulide was offered in Madhya Pradesh and Assam (Table 2; Fig. 1c). Nimesulide had the second-highest sales in the Haryana pVSZ (37\%) in 2017. Including only those regions where the drug was prevalent (Madhya Pradesh and Uttar Pradesh), sales of piroxicam remained stable (Table 2). In 2017, piroxicam was the most frequently bought drug in Madhya Pradesh (30\%), and the second most frequently bought drug in Uttar Pradesh (25\%).

\section{Nepal}

A total of 774 covert visits to 'Animal' pharmacies were made between 2012 and 2017, during which an NSAID was bought at 594 (76.7\%), the proportion declining over the course of the study (year, $b=$ $-0.211 \pm 0.04, t=5.00, P<0.0001)$. In all cases where an 'Animal' pharmacy did not sell an NSAID, no other drug was offered. Where the data were recorded $(n=593), 95 \%$ of NSAIDs were sold in injectable form, rather than a bolus.

Meloxicam was by far the most prevalent NSAID bought in 'Animal' pharmacies $(92.9 \%$ of NSAIDs, $n$ = 594), with five other drugs being sold in a few pharmacies (Table 3). The trend in the proportion of meloxicam bought varied between regions (Table 3). In the Western Terai, after an initial increase, there was evidence of a decline in the final survey in 2016 (Table 4; Fig. 2a). Sales of diclofenac, relative to all NSAIDs, were low in all surveys ( $n=8 / 594,1.3 \%)$, and the drug completely disappeared 
from pharmacies in two regions (Fig. 2b). On all eight occasions when diclofenac was bought, it was of human formulations in large $(30 \mathrm{ml})$ vials, and occurred both before and after the ban by the Government of India on the production of large vials. Those bought in the latest surveys $(2017 ; n=$ 2) were manufactured in March 2015. Nimesulide was bought with increasing frequency across the course of the study (Table 4), with a particularly sharp rise in the Western Terai $(b=1.437 \pm 0.54, t=$ 2.65, $P=0.008 ;$ Fig. 2c).

A total of 672 covert visits were made to 'Human' pharmacies, during which an NSAID was bought for use on cattle on only 30 (4.5\%) occasions. The drug bought was almost always diclofenac and was sold in $3 \mathrm{ml}(n=25)$ and $30 \mathrm{ml}$ vials $(n=5)$. Sales of diclofenac in 'Human' pharmacies significantly declined from $18 / 80(22.5 \%)$ in 2013 to $1 / 184(0.5 \%)$ in $2017\left(\chi^{2}{ }_{1}=37.03, P<0.0001\right)$. The nonNSAID paracetamol (acetaminophen) was also offered during two visits.

\section{Bangladesh}

Covert visits were made to a total of 215 pharmacies in the first survey, in $102(47 \%)$ of which NSAIDs were available to buy for veterinary use. In the second and third surveys, 128 (Sylhet, $n=66$; Khulna, $n=62$ ) and 129 (Sylhet, $n=71$; Khulna, $n=58$ ) pharmacies were visited, in which NSAIDs were available in 97\%. The absolute number of NSAID products stocked by pharmacies was 1095 (first survey $=340$, second survey $=374$ and third survey $=381$; Table 5 ). In those pharmacies stocking NSAIDs, the maximum number of different drugs was six, although most carried just one or two. Where the data were recorded $(n=1091), 84 \%$ of NSAIDs were available in injectable, rather than bolus, form ( $82-100 \%$ in different regions).

\section{Combining all regions and surveys, of the 1,095 NSAID products stocked, the majority were either}

ketoprofen or meloxicam (94\%; Table 5). Across the two repeat surveys in the Sylhet and Khulna pVSZs, there was a significant decline in the proportion of ketoprofen available (Fig. 3a) relative to
Commented [JM3]: TABLE 3; TABLE 4; FIGURE 2A; FIGURE 2B; FIGURE 2C 
meloxicam (Fig. $3 \mathrm{~b} ; \chi^{2}{ }_{1}=4.88, P=0.027$ ). The availability of other NSAIDs was low in all surveys, including diclofenac, stocks of which declined to zero in the final survey (Table 5; Fig.3c).

Diclofenac was available in only two large vial sizes (30 and $50 \mathrm{ml}$ ) and was manufactured by companies in Bangladesh and India. Where it was recorded $(n=1078), 59 \%$ of all NSAIDs were manufactured by a single company and $89 \%$ by just six companies

\section{Discussion}

The effect of differences in survey methods

Different methods were used in each of the countries surveyed. In India surveyors asked for a painkiller for their injured cow, in Nepal a prescription for diclofenac was presented to the pharmacist and in Bangladesh surveyors asked to see all NSAIDs stocked. These differences make comparisons between countries of the absolute levels of availability of drugs invalid. Asking for a specific drug is likely to increase the frequency with which that drug is offered by a pharmacist. However, the same method was used for surveys within each region and country, so we maintain that comparisons within regions and countries of trends over time are valid. Notwithstanding the above, in those countries (Nepal and Bangladesh) where diclofenac was specifically asked for, by the end of the survey period availability of this drug was very low. This suggests that we are justified in concluding that conservation organisations and government authorities in Nepal and Bangladesh have had greater success in removing veterinary diclofenac from pharmacies than they have in India.

Sales of the vulture-toxic NSAID diclofenac declined across all three countries surveyed, but the extent varied markedly, the drug all but disappearing from Nepal and Bangladesh, but remaining common in most regions of India. In contrast, the availability of the vulture-safe drug meloxicam increased, or remained high, across many regions, especially in Nepal. However, other NSAIDs, some 
of them known or suspected to be toxic to vultures, remained prevalent, especially ketoprofen in Bangladesh.

The decline in diclofenac

Although the governments of India, Nepal and Pakistan banned the veterinary use of diclofenac in 2006 and Bangladesh did so in 2010, our data reveal that the ban did not eliminate sales of the drug in India. By the start of our surveys (2012), six years after the ban, diclofenac still accounted for the largest share (44\%) of NSAIDs offered for sale in India. However, our data suggest that the strengthening of the ban to include all large (> $30 \mathrm{ml}$ ) vials of diclofenac may have been partially successful in reducing its prevalence in favour of other drugs. Over half the diclofenac bought after the strengthening of the ban was in large vials, and most of these consisted of old stock, manufactured before the ban. Notably, the large vials manufactured after 2015 were all illegally manufactured by Indian pharmaceutical companies.

The proportion of diclofenac sold in India declined over the period covered by our surveys. This may be attributable to awareness-raising programmes that occurred alongside our surveys, which included meetings with veterinarians, pharmacists, livestock owners and veterinary and pharmacy associations. Variation in the implementation of such advocacy may be part of the reason for the variation in trends in diclofenac sales between regions. For instance, in Assam, diclofenac sales dropped to zero after five annual surveys; whereas, in Gujarat (Central and Southern), after a decline between 2012 and 2013, sales increased again by the time of the next survey and awareness-raising programme in 2017. Thus, awareness-raising needs to be continued if it is to be effective.

The slow and incomplete reduction in diclofenac availability in veterinary pharmacies is the probable cause of the decline in the prevalence and concentration of diclofenac in cattle carcasses since 2006 
(Cuthbert et al. 2014a). These changes may be starting to have an impact on vulture populations, with the declines in White-rumped Gyps bengalensis, Indian $G$. indicus and Slender-billed Vultures $G$. tenuirostris in India having slowed since the ban on diclofenac (Prakash et al. 2017).

In contrast to the situation in India, diclofenac virtually disappeared from pharmacies in both Nepal and Bangladesh. This may have been due to effective advocacy and education, as well as strong government support, especially in promoting meloxicam in Nepal. However, the fact that most diclofenac is manufactured by Indian companies may contribute significantly. The one Nepali company found to be manufacturing $30 \mathrm{ml}$ vials of diclofenac for human use during the first 'Human' pharmacy survey, voluntarily stopped after being asked to do so by conservationists. Diclofenac could still find its way into cattle via importation across the long, permeable borders with India, where it is more easily obtainable (K. Paudel, unpublished information), although the rapid partial recovery of White-rumped Vulture populations in Nepal since 2013 (Galligan et al. 2019) suggests that this is not happening on a large scale. Meanwhile, the recent strengthening of the ban in India will also reduce the risk of diclofenac imports and benefit vultures in Nepal and Bangladesh.

The rise of meloxicam

Sales of meloxicam increased in some of the regions we surveyed, and was the most common drug sold in pharmacies in Nepal. In India and Bangladesh, although availability increased in some regions, meloxicam was rarely the most common NSAID sold. Meloxicam is the only NSAID that has been shown through safety testing (Swan et al. 2006b; Swarup et al. 2007) to be non-toxic to Gyps vultures at doses they are likely to be exposed to in the wild. It has therefore been promoted to pharmacists and cattle-owners by conservationists across South Asia. Such advocacy has been particularly successful in Nepal. This has been aided by national and local government bodies promoting meloxicam after the ban on veterinary diclofenac in 2006, and later instigating a 
diclofenac-for-meloxicam exchange programme in 2010. Similar advocacy in Bangladesh, including distributing meloxicam to pharmacists and veterinarians free of charge, has helped this drug to maintain its market share, although it lags well behind ketoprofen.

Meloxicam is an effective painkiller. In a review of experimental and clinical studies, $79 \%$ of 117 studies reported positive effects of the drug on domesticated animals (SAVE 2016). However, many formulations of meloxicam are disliked by users because they cause the animal pain when injected, which is associated with the high $\mathrm{pH}$ and high osmolarity of meloxicam formulations produced in India (Cuthbert et al. 2014b), which are higher than that of the original formulation produced in Europe. Subsequently, a number of regional pharmaceutical companies have been able to replicate the original meloxicam formulation after the developer relaxed its patent (C. Bowden, unpublished information).

\section{The appearance of new NSAIDs}

Several other NSAIDs are widely available, some of which are known to be toxic to vultures, the most prevalent being nimesulide and ketoprofen. With the decline of the once-ubiquitous diclofenac, there are now gaps in the market that pharmaceutical companies are keen to fill with alternatives. For instance, in Nepal, one company promoted its nimesulide product by distributing it without charge (K. Bhusal, unpublished information).

In a nationwide study of dead vultures in India, post-mortem analysis revealed nimesulide residues in five (of 62) dead vultures, four of which had extensive visceral gout, a symptom of NSAID toxicity formerly only associated with high diclofenac residues (Cuthbert et al. 2016). Confirming that nimesulide is indeed toxic to Gyps vultures, two captive Cape Griffon Vultures G. coprotheres that 
were unable to be released due to injury were dosed (by oral gavage) with nimesulide during safety testing, and died displaying symptoms of NSAID toxicity (Galligan et al. in prep.).

Ketoprofen has been shown in safety tests on captive birds to be nephrotoxic to vultures (Naidoo et al. 2010). Although the drug has not yet been found in carcasses of wild vultures, lethal concentrations have been found in cattle carcasses in India (Taggart et al. 2009). Following advocacy by conservationists, the Government of Bangladesh banned veterinary use of ketoprofen in the two pVSZs in 2016, but this appears to have been only partially successful in reducing the drug's availability, despite an intensive awareness-raising campaign and promotion of meloxicam. One reason for its apparent resilience in the market may be the unfounded rumour that ketoprofen is safe to use on pregnant animals while meloxicam is not, which is not substantiated by published experimental and clinical studies, none of which even examined ketoprofen and pregnancy (SAVE 2016). Conversations with pharmacy owners during the third survey revealed that they were almost all aware of the ban on ketoprofen and that some were selling stocks acquired before the ban (A.B.M.S. Alam, unpublished information).

Other NSAIDs were available, usually at low prevalence, but including several known or suspected to be toxic to vultures, such as aceclofenac and flunixin. Aceclofenac is structurally very similar to diclofenac and is metabolised to the latter in various species of mammal, including cattle (Sharma 2012; Galligan et al. 2016); therefore, aceclofenac is expected to have the same effect on vultures as diclofenac (Galligan et al. 2016). Although almost always sold in bolus form in our survey, injectable aceclofenac has recently been approved by the Indian government (C. Bowden, unpublished information). Several formulations are already available, so it could become a more popular veterinary drug in the future. Given the high levels of diclofenac that are formed in cattle tissues soon after injection of aceclofenac (Galligan et al. 2016), any future increase in sales of aceclofenac is expected to have devastating effects on the remaining populations of vultures. 
Elevated flunixin residues, along with severe visceral gout, have been found in the carcasses of

Eurasian Griffon Vultures Gyps fulvus in Spain (Zorrilla et al. 2014, R. Mateo, Pers. Comm.), the first reported instances of NSAID poisoning in wild vultures outside of South Asia. Flunixin was also responsible for the death of two captive Rüppell's Vultures G. rueppellii and one captive African White-backed Vulture G. africanus at a zoo in Rome, Italy (Eleni et al. 2019).

More encouraging was the increasing presence of tolfenamic acid, especially in Nepal and Bangladesh. Initial safety testing of this drug on Gyps vultures suggests that it may be non-toxic to vultures (Sharma et al. in prep). This would provide veterinarians and farmers with an additional vulture-safe drug, alongside meloxicam. One other drug, piroxicam, was also commonly available in Madhya Pradesh and Uttar Pradesh in the last surveys in 2017, but little is known about its toxicity to vultures.

\section{Conservation recommendations}

The biggest threat to vultures continues to be the wide availability of diclofenac, despite having been banned by governments across South Asia. There is a clear need for greater implementation of these bans, especially in India. Similarly, the ban on ketoprofen in pVSZs in Bangladesh needs to be extended throughout this (as proposed by the Government of Bangladesh in the Bangladesh Vulture Conservation Plan (2016-2025)) and other vulture range countries. There should also be bans on the veterinary use of aceclofenac and nimesulide, which have growing market shares.

Although awareness-raising has had some success, actions directed at pharmaceutical companies themselves may have a greater impact. This may particularly be the case in Bangladesh, where only a small number of companies manufacture ketoprofen. These companies also produce meloxicam and 
tolfenamic acid, so their share of the drug market may not necessarily be adversely affected if they stop ketoprofen production.

A total of eleven different NSAIDs were recorded in this study, yet the results of safety testing have only been published for three of these drugs (diclofenac, meloxicam and ketoprofen). Such testing has been solely funded by conservation non-governmental agencies and academic sources, rather than governments or pharmaceutical companies within vulture-range countries. There is an urgent need to test these other drugs for toxicity to vultures experimentally, especially as other evidence of toxicity already exists for some of them, e.g. flunixin and nimesulide. Currently, meloxicam is the only NSAID that has been established as vulture-safe. Further safety testing of NSAIDS to identify other vulture-safe drugs, would give more choice to veterinarians and cattle-owners. Although meloxicam is known to be safe, in this survey up to half of products of this drug also contained paracetamol (India, 35\%; Nepal, 43\%; Bangladesh, 51\%), for which there is no information regarding its safety to vultures, so the toxicity of this common painkiller also needs to be assessed. New veterinary NSAIDs should be tested for toxicity to vultures prior to their receiving government approval through the region. However, even more important than safety testing is that governments take action when the results from safety tests are available. Except for the ban on ketoprofen in the Bangladesh pVSZs, governments have not taken such action for other NSAIDs known to be toxic to vultures, such as aceclofenac or ketoprofen. Given that most veterinary NSAIDs used in South Asia are manufactured in India, this is an action which should be considered by the Indian government as part of their National Action Plan for Vulture Conservation (2019-2024) and their role in the Regional Declaration on the Conservation of South Asia's Critically Endangered Vulture Species (Anon 2012), which commits signatories to identifying and preventing the veterinary use of all vulture-toxic NSAIDs.

\section{Acknowledgements}


480 Cuthbert, R.J., Taggart, M.A., Prakash, V., Chakraborty, S.S., Deori, P., Kulkarni, M., Ranade, S., Saini. M.,

We wish to thank the Ministry of Environment, Forest and Climate Change, Government of India, the Ministry of Forests and Environment, Government of Nepal, the Forest Department and the Ministry of Environment, Forest and Climate Change, Government of Bangladesh and IUCN Bangladesh for their ongoing support for vulture conservation. The manuscript was greatly improved by the comments of Rubén Moreno-Opo and an anonymous reviewer. This work was funded by the RSPB.

\section{References}

Anon (2012) Regional Declaration on the Conservation of South Asia's Critically Endangered Vulture Species. Governments of Bangladesh, India, Nepal and Pakistan, Delhi, May 2012.

Athanassoulis, N. and Wilson, J. (2009) When is deception in research ethical? Clinical ethics 4: 4449.

Chaudhry, J. M. I., Ogada, D. L., Malik, R. N., Virani, M. Z. and Giovanni, M. D. (2012) First evidence that populations of the critically endangered Long-billed Vulture Gyps indicus in Pakistan have increased following the ban of the toxic veterinary drug diclofenac in South Asia. Bird Cons. Int. 22: 389-397.

Cuthbert, R. J., Dave, R., Chakraborty, S. S., Kumar, S., Prakash, S., Ranade, S. P. and Prakash, V. (2011) Assessing the ongoing threat from veterinary non-steroidal anti-inflammatory drugs to critically endangered Gyps vultures in India . Oryx 45: 420-426. 
Cuthbert, R.J., Paudel, S., Chaudhary, A., Kaphle, K., Thapa, J., Subedi, T.R. and Taggart, M.A. (2014b) Aligning species conservation with animal welfare: formulation of vulture-safe meloxicam manufactured in South Asia and the reaction of goats to its administration. RSPB Research Report No. 52. Royal Society for the Protection of Birds, Sandy, Bedfordshire, UK.

Cuthbert, R. J., Taggart, M. A., Mohini, S., Sharma, A., Das, A., Kulkarni, M. D., Deori, P., Ranade, S., Shringarpure, R. N., Galligan, T. H. and Green, R. E. (2016) Continuing mortality of vultures in India associated with illegal veterinary use of diclofenac and a potential threat from nimesulide. Oryx 50: 104-112.

Eleni, C., Neri, B., Giannetti, L., Grifoni, G., Meoli, R., Stravino, F., Friedrich, K.G., Scholl, F., Di Cerbo, P. and Battisti, A. (2019) Death of captive-bred vultures caused by flunixin poisoning in Italy. Environ. Toxicol. Pharm. 68: 91-93.

Flourie, T., Cromarty, D., Duncan, N., Wolter, K. and Naidoo, V. (2015) The safety and pharmacokinetics of carprofen, flunixin and phenylbutazone in the Cape Vulture (Gyps coprotheres) following oral exposure. PLoS One 10: e0141419.

Galligan, T. H., Taggart, M. A., Cuthbert, R. J., Svobodova, D., Chipangura, J., Alderson, D., Prakash, V. M. and Naidoo, V. (2016) Metabolism of aceclofenac in cattle to vulture-killing diclofenac. Cons. Biol. 30: 1122-1127.

Galligan, T.H., Bhusal, K.P., Paudel, K., Chapagain, D., Joshi, A.B., Chaudhary, I.P., Chaudhary, A., Baral, H.M., Cuthbert, R.J. and Green, R.E. (2019) Partial recovery of Critically Endangered Gyps vulture populations in Nepal. Bird Cons. Int. doi:10.1017/S0959270919000169. 
Green, R. E., Newton, I., Shultz, S., Cunningham, A. A., Gilbert, G., Pain, D. J. and Prakash, V. (2004) Diclofenac poisoning as a cause of vulture population declines across the Indian subcontinent. J. App. Ecol. 41: 793-800.

Green, R. E., Taggart, M. A., Senacha, K. R., Raghavan, B., Pain, D. J., Jhala, Y. and Cuthbert, R. (2007) Rate of decline of the Oriental White-Backed Vulture population in India estimated from a survey of diclofenac residues in carcasses of ungulates. PIOS ONE 2: e686.

Naidoo, V., Wolter, K., Cromarty, D., Diekman, M., Duncan, N., Meharg, A. A., Taggart, M. A., Venter, L. and Cuthbert, R. (2010) Toxicity of non-steroidal anti-inflammatory drugs to Gyps vultures: a new threat from ketoprofen. Biol. Lett. 6: 339-341.

Naidoo, V., Taggart, M. A., Duncan, N., Wolter, K., Chipangura, J., Green, R. E. and Galligan, T. H. (2018) The use of toxicokinetics and exposure studies to show that carprofen in cattle tissue could lead to secondary toxicity and death in wild vultures. Chemosphere 190: 80-89.

Oaks, J. L., Gilbert, M., Virani, M. Z., Watson, R. T., Meteyer, C. U., Rideout, B. A., Shivaprasad, H. L., Ahmed, S., Chaudhry, M. J. I., Arshad, M., Mahmood, S., Ali, A. and Khan, A. A. (2004) Diclofenac residues as the cause of population decline of vultures in Pakistan. Nature 427: 630-633.

Prakash, V., Green, R. E., Pain, D. J., Ranade, S. P., Saravanan, S., Prakash, N., Venkitachalam, R., Cuthbert, R., Rahmani, A. R. and Cunningham, A. A. (2007) Recent changes in populations of resident Gyps vultures in India. J. Bomb. Nat. Hist. Soc. 104:129-135. 
Prakash, V., Galligan, T. H., Chakraborty, S. S., Dave, R., Kulkarni, M. D., Prakash, N., Shringarpure, R. N., Ranade, S. P. and Green, R. E. (2017) Recent changes in populations of Critically Endangered Gyps vultures in India. Bird Cons. Int. 29: 55-70.

SAVE 2016 NSAID Alerts. https://save-vultures.org/alerts/ Downloaded on 20 December 2017.

Shultz, S., Baral, H. S., Charman, S., Cunningham, A. A., Das, D., Ghalsasi, G. R., Goudar, M. S., Green, R. E., Jones, A., Nighot, P., Pain, D. J. and Prakash, V. (2004) Diclofenac poisoning is widespread in declining vulture populations across the Indian subcontinent. Proc. Roy. Soc. Lond. B (Supplement) 271: S458-S460.

Spicker, P. (2011) Ethical covert research. Sociology, 45: 118-133.

Swan, G. E., Cuthbert, R., Quevedo, M., Green, R. E., Pain, D. J., Bartels. P., Cunningham, A. A., Duncan, N., Meharg, A. A., Oaks. L., Jones, J. M., Shultz, S., Taggart, M. A., Verdoorn, G. and Wolter, K. (2006a) Toxicity of diclofenac to Gyps vultures. Biol. Lett. 2: 279-282.

Swan, G., Naidoo, V., Cuthbert, R., Green, R. E., Pain, D. J., Swarup, D., Prakash, V., Taggart, M., Bekker, L., Das, D., Diekmann, J., Diekmann, M., Killian, E., Meharg, A., Patra, R. C. , Saini, M. and Wolter, K. (2006b) Removing the threat of diclofenac to Critically Endangered Asian Vultures. PLoS Biol. 4: 396-402.

Swarup, D., Patra, R.C., Prakash, V., Cuthbert, R., Das, D., Avari, D.J., Pain, D.J., Green, R.E., Sharma, A.K., Saini, M., Das, D. and Taggart, M. (2007) Safety of meloxicam to critically endangered Gyps vultures and other scavenging birds in India. Anim. Conserv. 10: 192-198. 
Taggart, M. A., Senacha, K. R., Green, R. E., Jhala, Y., Raghavan, B., Rahmani, A., Cuthbert, R., Pain, D. J. and Meharg, A. A. (2007) Diclofenac residues in carcasses of domestic ungulates available to vultures in India. Environ. Int. 33: 759-765.

Taggart M.A., Senacha K.R., Green R.E., Cuthbert R., Jhala Y.V., Meharg A.A., Mateo R. and Pain D.J. (2009) Analysis of Nine NSAIDs in Ungulate Tissues Available to Critically Endangered Vultures in India. Environ. Sci. Technol. 43, 4561-4566.

Zorrilla, I., Martinez, R., Taggart, M. A. and Richards, N. (2014) Suspected flunixin poisoning of a wild Eurasian griffon vulture from Spain. Cons. Biol. 29: 587-592. 
Table 1. The percentage of pharmacies that offered for sale the four most common NSAIDs for use in cattle, during covert (undercover) surveys in various regions of India in 2012-2017. $\mathrm{N}=$ the number of pharmacies that offered an NSAID.

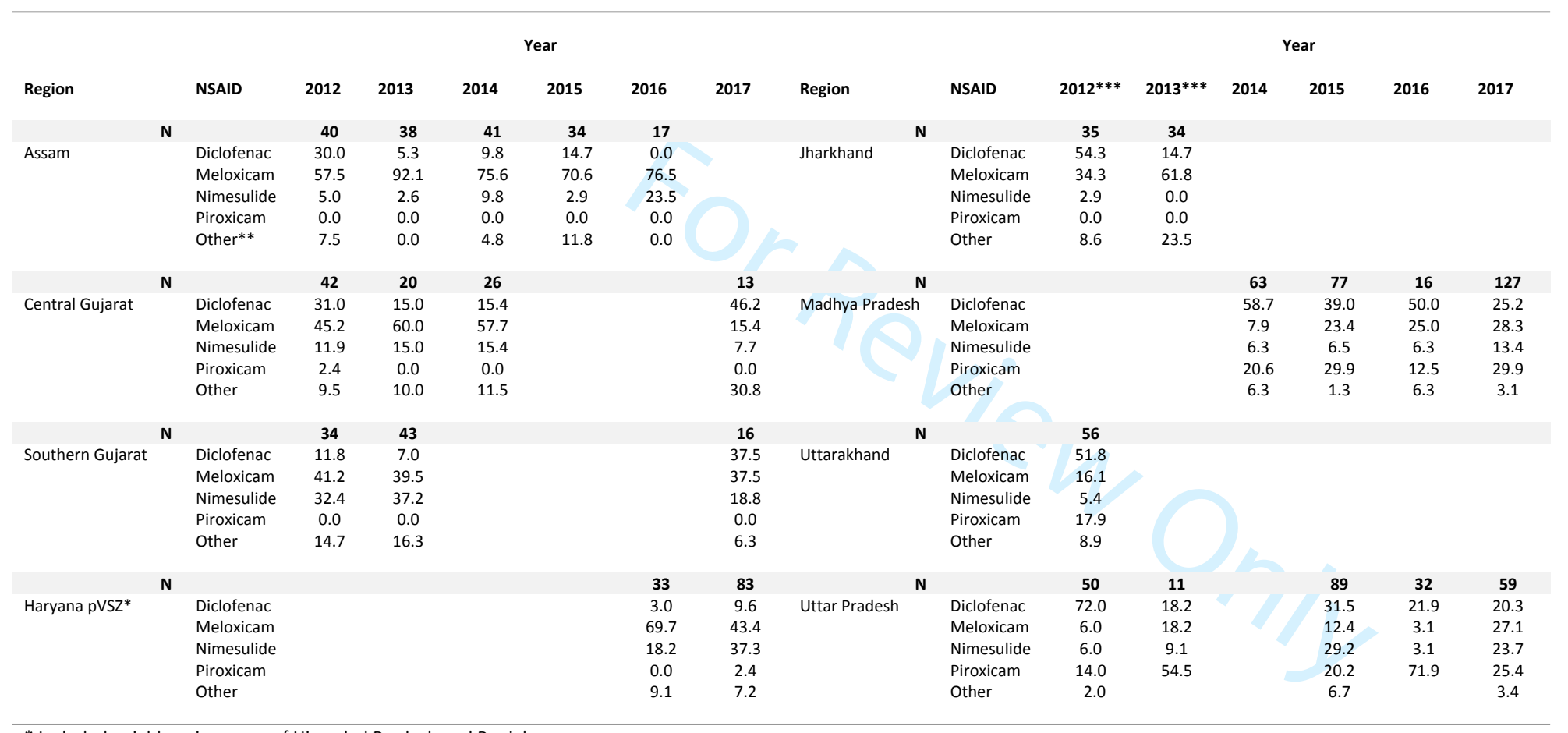

Included neighbouring areas of Himachal Pradesh and Punjab

** 'Other' NSAIDs include: aceclofenac, metamizole (Analgin), ketoprofen, mefenamic acid, phenylbutazone and tolfenamic acid

*** A different method was used in surveys in 2012 and 2013 in Jharkhand, Uttarakhand and Uttar Pradesh (see Methods) 
Table 2. Trends in the proportion of four NSAIDs offered for sale for use in cattle during covert (undercover) surveys of pharmacies in five regions of India between 2012 and 2017.

\begin{tabular}{lllllllll}
\hline & \multicolumn{9}{l}{ (a) Diclofenac } & \multicolumn{1}{l}{ (b) Meloxicam } \\
\hline Region & $b$ & SE & $t$ & $P$ & $b$ & SE & $t$ & $P$ \\
\hline Assam & $-\mathbf{0 . 4 7 1}$ & $\mathbf{0 . 2 0}$ & $\mathbf{2 . 3 9}$ & $\mathbf{0 . 0 1 8}$ & 0.112 & 0.14 & 0.82 & 0.41 \\
Central Gujarat & 0.109 & 0.14 & 0.81 & 0.42 & -0.209 & 0.13 & 1.59 & 0.11 \\
Southern Gujarat & $\mathbf{0 . 3 7 4}$ & $\mathbf{0 . 1 5}$ & $\mathbf{2 . 5 5}$ & $\mathbf{0 . 0 1 2}$ & -0.029 & 0.12 & 0.24 & 0.81 \\
Madhya Pradesh & $\mathbf{- 0 . 4 2 6}$ & $\mathbf{0 . 1 0}$ & $\mathbf{4 . 1 4}$ & $<\mathbf{0 . 0 0 0 1}$ & $\mathbf{0 . 3 4 8}$ & $\mathbf{0 . 1 2}$ & $\mathbf{2 . 8 3}$ & $\mathbf{0 . 0 0 5}$ \\
Uttar Pradesh & -0.306 & 0.20 & 1.55 & 0.12 & $\mathbf{0 . 5 0 9}$ & $\mathbf{0 . 2 3}$ & $\mathbf{2 . 1 9}$ & $\mathbf{0 . 0 3}$ \\
& & & & & & & & \\
\hline & (c) Nimesulide & & & (d) Piroxicam & & \\
\hline Region & $b$ & SE & $t$ & $P$ & $b$ & SE & $t$ & $P$ \\
\hline Assam & 0.406 & 0.24 & 1.70 & 0.09 & & & & \\
Central Gujarat & -0.058 & 0.19 & 0.30 & 0.76 & & & & \\
Southern Gujarat & -0.155 & 0.14 & 1.10 & 0.28 & & & & \\
Madhya Pradesh & 0.318 & 0.18 & 1.80 & 0.07 & 0.089 & 0.08 & 1.05 & 0.29 \\
Uttar Pradesh & -0.210 & 0.20 & 1.03 & 0.30 & 0.205 & 0.18 & 1.14 & 0.26 \\
& & & & & & & & \\
\hline
\end{tabular}


Table 3. The percentage of pharmacies that offered for sale six NSAIDs for use in cattle, during covert (undercover) surveys in various regions of Nepal, 2012-2017. $\mathrm{N}=$ the number of pharmacies that offered an NSAID.

\begin{tabular}{|c|c|c|c|c|c|c|c|c|}
\hline \multirow[b]{2}{*}{ Region } & & \multirow[b]{2}{*}{ NSAID } & \multicolumn{6}{|c|}{ Year } \\
\hline & $\mathbf{N}$ & & 2012 & 2013 & 2014 & 2015 & $\begin{array}{c}2016 \\
38\end{array}$ & $\begin{array}{c}2017 \\
68\end{array}$ \\
\hline \multirow{6}{*}{ Eastern Terai } & & Diclofenac & & & & & 2.6 & 1.2 \\
\hline & & Meloxicam & & & & & 79.0 & 89.9 \\
\hline & & Nimesulide & & & & & 5.3 & 1.2 \\
\hline & & Piroxicam & & & & & 2.6 & 0.0 \\
\hline & & Ketoprofen & & & & & 0.0 & 1.2 \\
\hline & & Tolfenamic acid & & & & & 10.5 & \\
\hline & $\mathbf{N}$ & & & 36 & 65 & 71 & & \\
\hline \multirow[t]{6}{*}{ Western Pahad } & & Diclofenac & & 0.0 & 0.0 & 0.0 & & \\
\hline & & Meloxicam & & 100 & 100 & 95.8 & & \\
\hline & & Nimesulide & & 0.0 & 0.0 & 2.8 & & \\
\hline & & Piroxicam & & 0.0 & 0.0 & 0.0 & & \\
\hline & & Ketoprofen & & 0.0 & 0.0 & 1.4 & & \\
\hline & & Tolfenamic acid & & 0.0 & 0.0 & 0.0 & & \\
\hline & 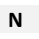 & & 21 & 72 & 56 & 15 & 51 & \\
\hline \multirow{6}{*}{\multicolumn{2}{|c|}{ Western Terai }} & Diclofenac & 9.5 & 4.2 & 0.0 & 0.0 & 0.0 & \\
\hline & & Meloxicam & 90.5 & 95.8 & 98.2 & 100 & 84.3 & \\
\hline & & Nimesulide & 0.0 & 0.0 & 1.8 & 0.0 & 13.7 & \\
\hline & & Piroxicam & 0.0 & 0.0 & 0.0 & 0.0 & 0.0 & \\
\hline & & Ketoprofen & 0.0 & 0.0 & 0.0 & 0.0 & 0.0 & \\
\hline & & Tolfenamic acid & 0.0 & 0.0 & 0.0 & 0.0 & 2.0 & \\
\hline
\end{tabular}


Table 4. Trends in the proportion of diclofenac and meloxicam offered for sale for use in cattle during covert (undercover) surveys of 'Animal' pharmacies in three regions of Nepal, 2012-2017. Models for the Western Pahad region did not converge. Superscript '2' denotes quadratic effect.

\begin{tabular}{|c|c|c|c|c|c|c|c|c|}
\hline & Diclofe & & & & Melox & & & \\
\hline Region & $b$ & SE & $t$ & $P$ & $b$ & SE & $t$ & $P$ \\
\hline Eastern Terai & -0.594 & 1.43 & 0.42 & 0.68 & 0.843 & 0.56 & 1.50 & 0.14 \\
\hline & & & & & -0.488 & 0.2 & 2.44 & 0.02 \\
\hline
\end{tabular}


Table 5. The percentage (of all NSAIDs stocked) of seven NSAIDs available for use on cattle, during covert (undercover) surveys of pharmacies in three regions of Bangladesh, 2014-2018. $\mathrm{N}=$ the total number of NSAIDs stocked by pharmacies. The first survey covered the whole of the country.

\begin{tabular}{|c|c|c|c|c|c|}
\hline BANGLADESH & & & & Year & \\
\hline \multirow[t]{2}{*}{ Region } & & NSAID & 2014 & 2015/16 & 2018 \\
\hline & $\mathbf{N}$ & & 340 & & \\
\hline \multirow{7}{*}{ Whole country } & & Diclofenac & 6.5 & & \\
\hline & & Meloxicam & 24.7 & & \\
\hline & & Nimesulide & 0.0 & & \\
\hline & & Ketoprofen & 67.1 & & \\
\hline & & Tolfenamic acid & 0.3 & & \\
\hline & & Flunixin & 0.3 & & \\
\hline & & Phenylbutazone & 1.2 & & \\
\hline \multirow{8}{*}{ Sylhet pVSZ } & $\mathbf{N}$ & & & 197 & 197 \\
\hline & & Diclofenac & & 0.0 & 0.0 \\
\hline & & Meloxicam & & 29.9 & 29.9 \\
\hline & & Nimesulide & & 0.0 & 0.0 \\
\hline & & Ketoprofen & & 67.0 & 67.0 \\
\hline & & Tolfenamic acid & & 3.0 & 3.0 \\
\hline & & Flunixin & & 0.0 & 0.0 \\
\hline & & Phenylbutazone & & 0.0 & 0.0 \\
\hline & $\mathrm{N}$ & & & 177 & 184 \\
\hline \multirow[t]{7}{*}{ Khulna pVSZ } & & Diclofenac & & 1.7 & 0.0 \\
\hline & & Meloxicam & & 21.5 & 37.0 \\
\hline & & Nimesulide & & 0.0 & 0.0 \\
\hline & & Ketoprofen & & 72.3 & 56.0 \\
\hline & & Tolfenamic acid & & 3.4 & 5.4 \\
\hline & & Flunixin & & 0.6 & 1.6 \\
\hline & & Phenylbutazone & & 0.6 & 0 \\
\hline
\end{tabular}




\section{Figure legends}

Figure 1. Percentage of pharmacies that offered for sale for use in cattle (a) diclofenac, (b) meloxicam and (c) nimesulide during covert (undercover) surveys of pharmacies in five regions of India from 2012 to 2017. Regression lines from predicted values fitted from logistic regression model included to illustrate trends in sales of NSAIDs in the five regions. Note varying scale of $y$-axis.

Figure 2. Percentage of pharmacies that offered for sale for use in cattle (a) meloxicam, (b) diclofenac and (c) nimesulide during covert (undercover) surveys of pharmacies in three regions of Nepal from 2012 to 2017. Regression line from predicted values fitted from logistic regression model for the Western Terai region included to illustrate trends in sales of NSAIDs. No regression lines included for Eastern Terai, as only two surveys conducted. Models of trends in Western Pahad region did not converge. Note varying scale of $y$-axis.

Figure 3. Percentage of all NSAIDs stocked by pharmacies for use in cattle that were (a) ketoprofen, (b) meloxicam and (c) diclofenac during covert (undercover) surveys of pharmacies in Bangladesh from 2014 to 2018. The first survey covered the whole country, whereas later surveys were conducted in two provisional Vulture Safe Zones. Regression lines not included as regions only surveyed in 1-2 years. Note varying scale of $y$-axis. 


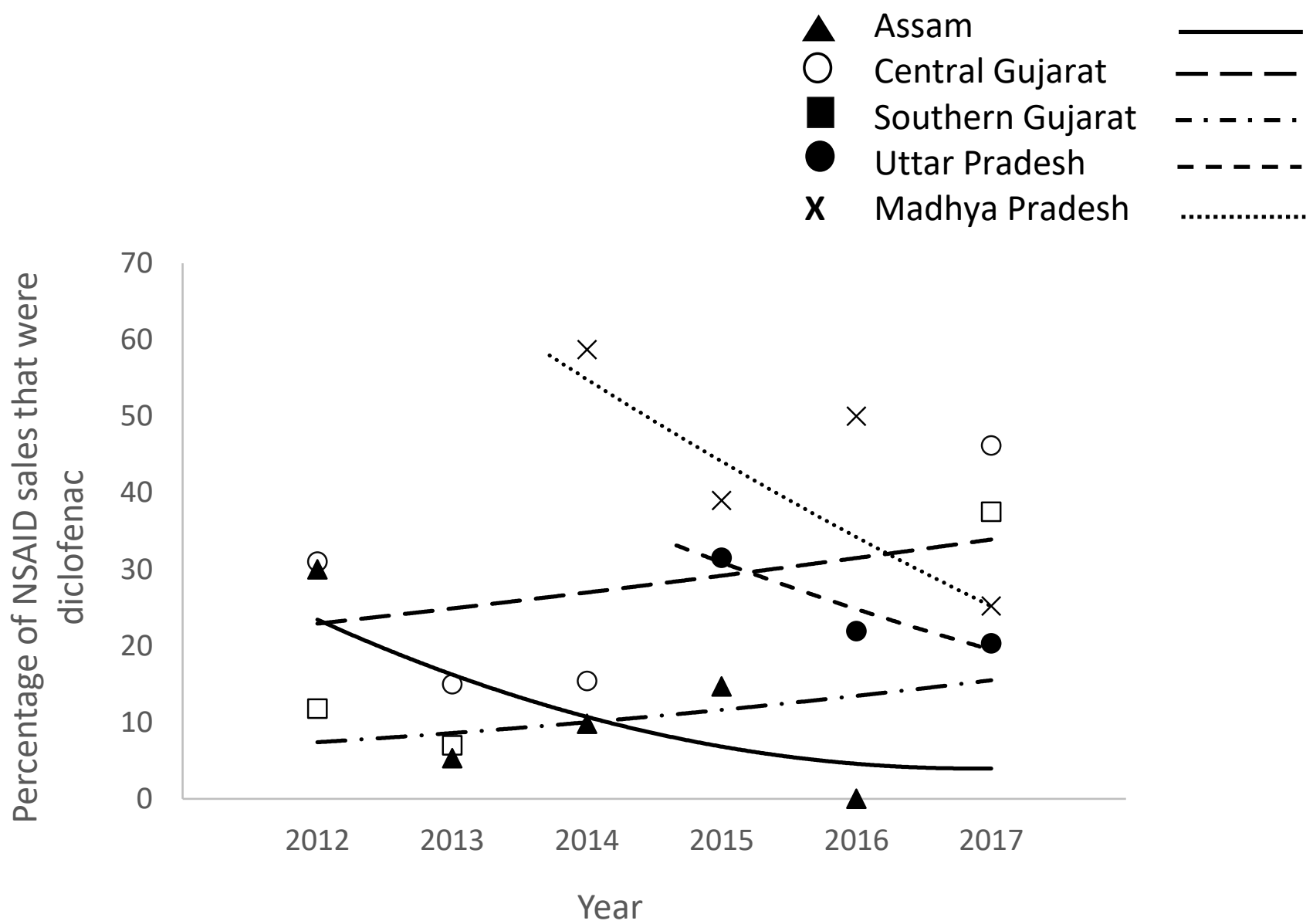

Figure 1a 
A Assam

C Central Gujarat

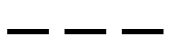

- Southern Gujarat - . - . - .

- Uttar Pradesh

X Madhya Pradesh

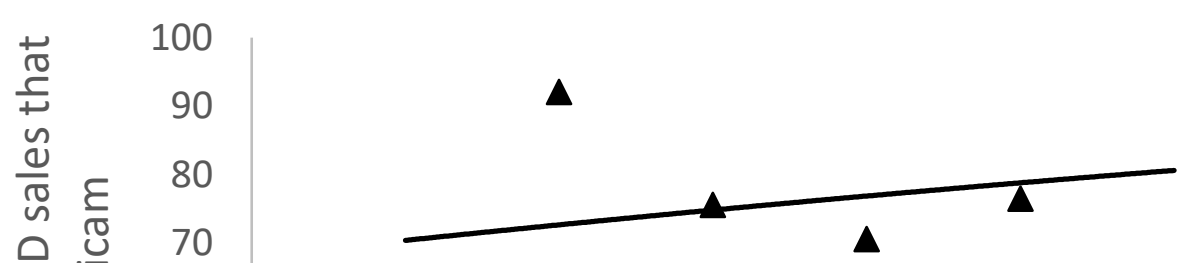

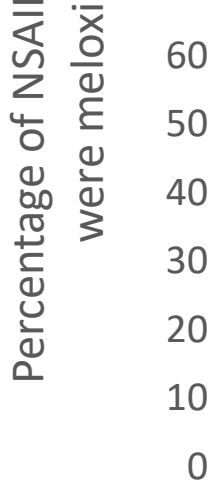
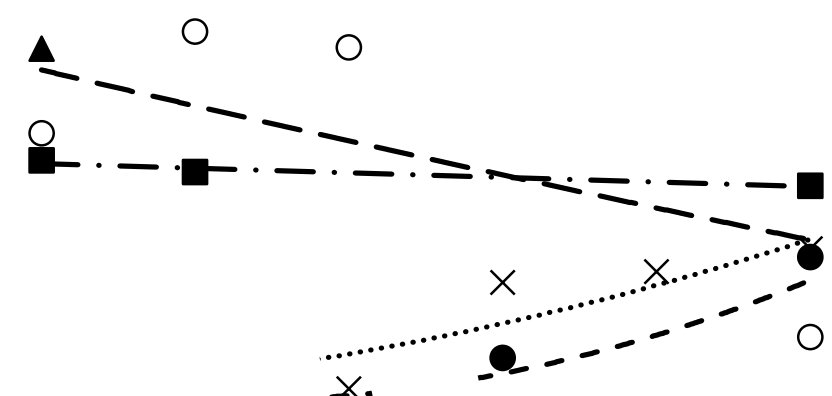

$x$.

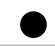

2012

2013

2014

20152016

2017

Year

Figure 1b 


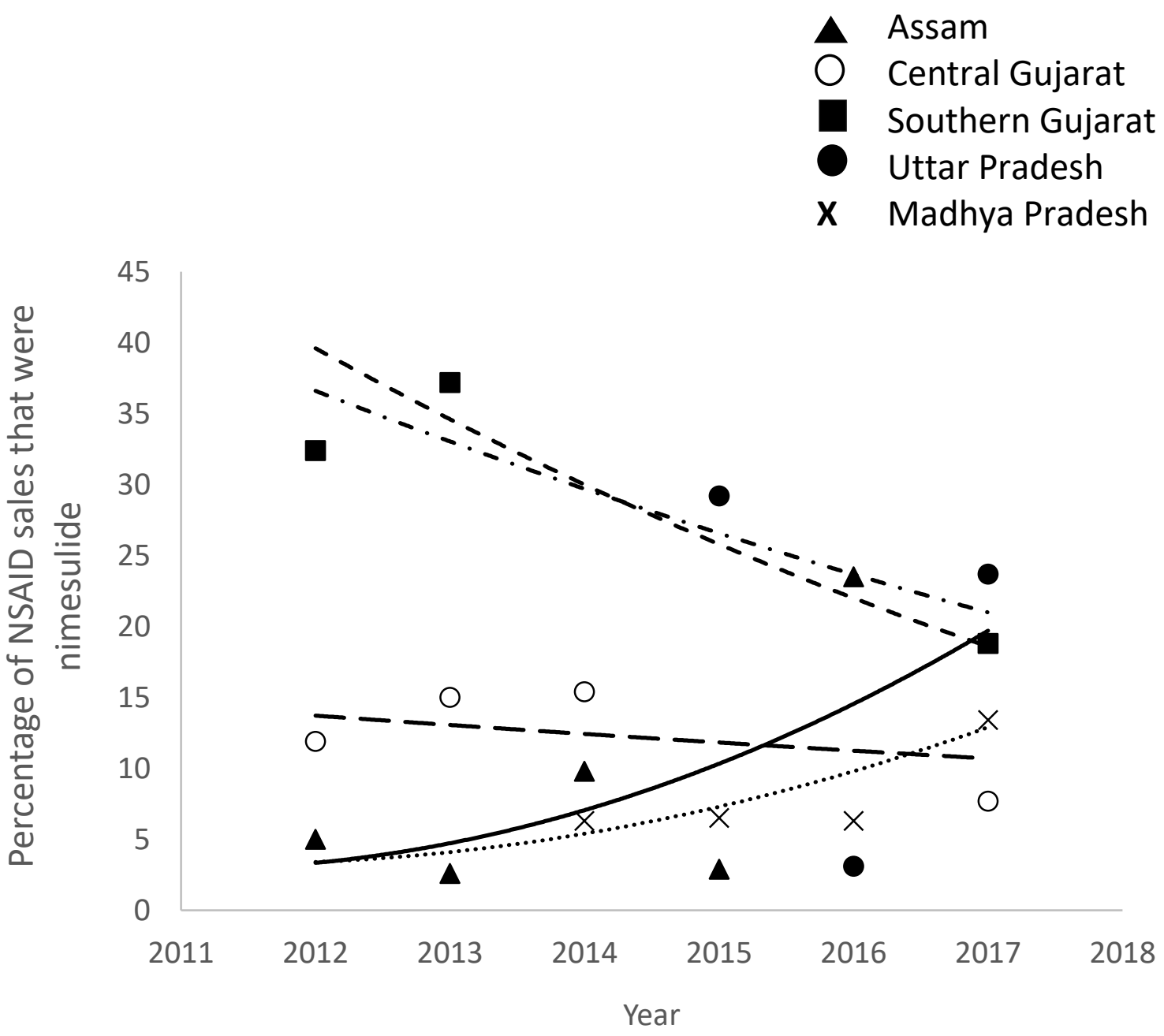

Figure 1c 
A Western Pahad

$\square$ Western Terai

- Eastern Terai

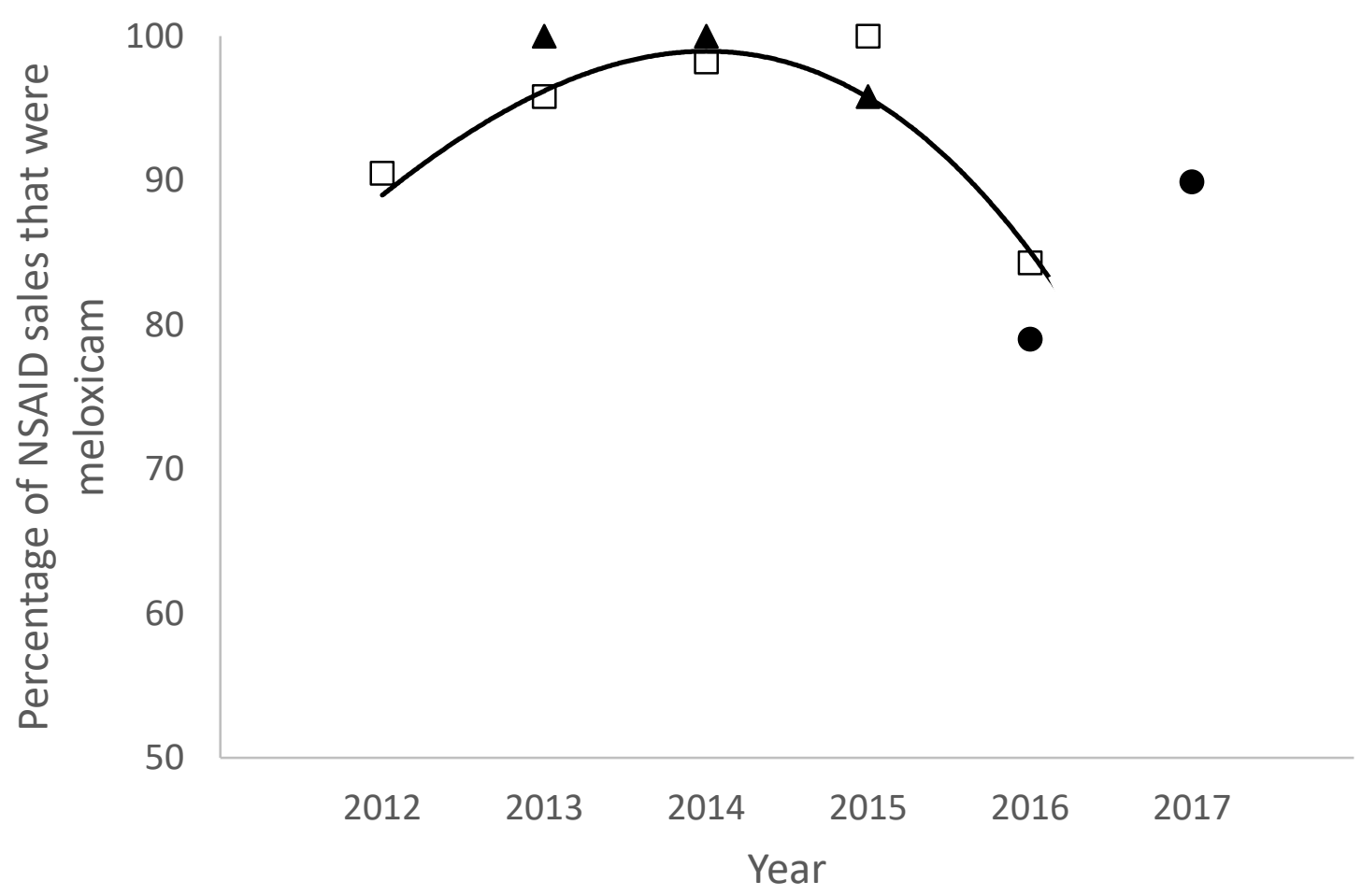

Figure 2a 
A Western Pahad

$\square$ Western Terai

- Eastern Terai

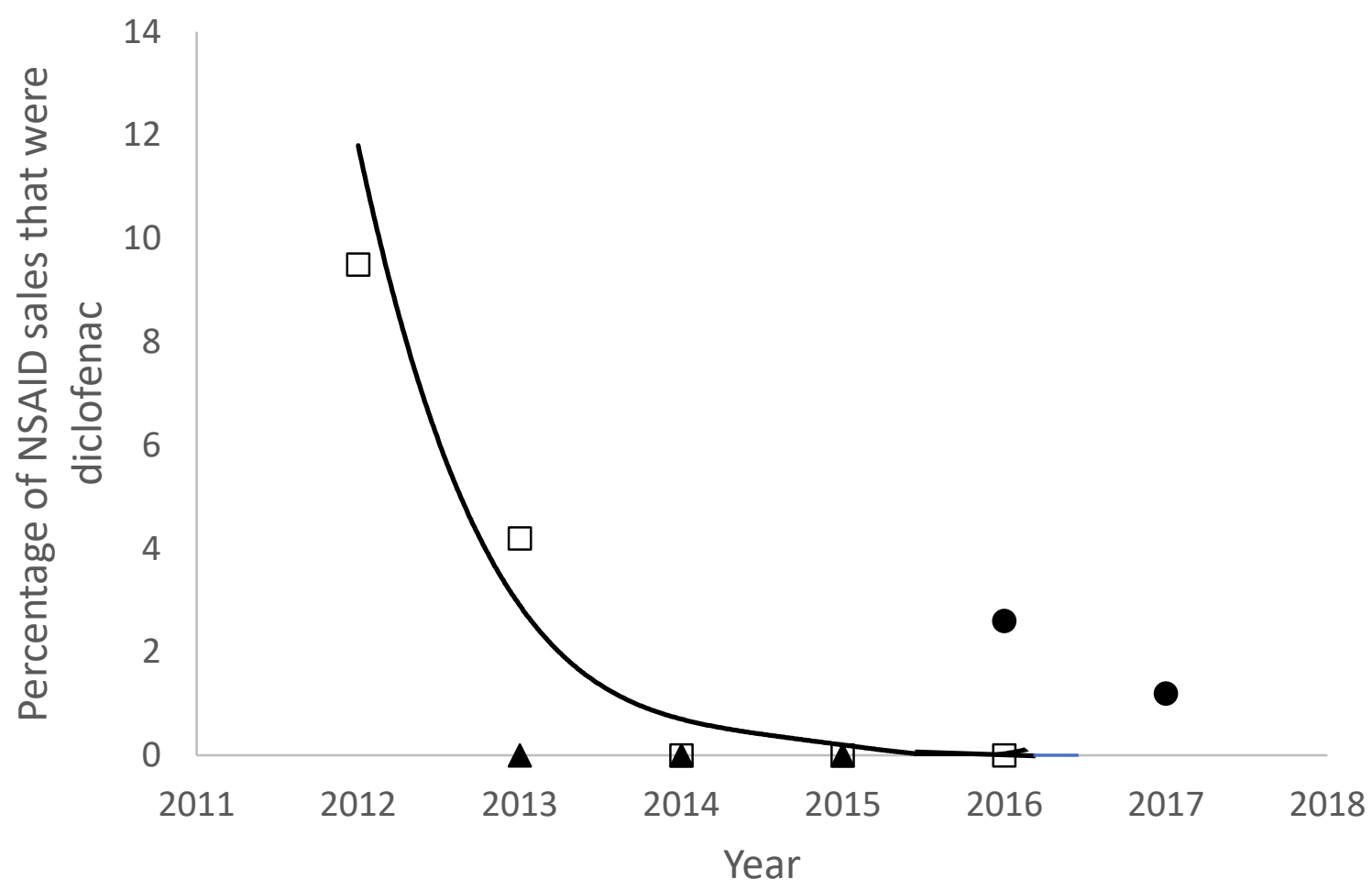

Figure 2b 
A Western Pahad

$\square$ Western Terai

- Eastern Terai

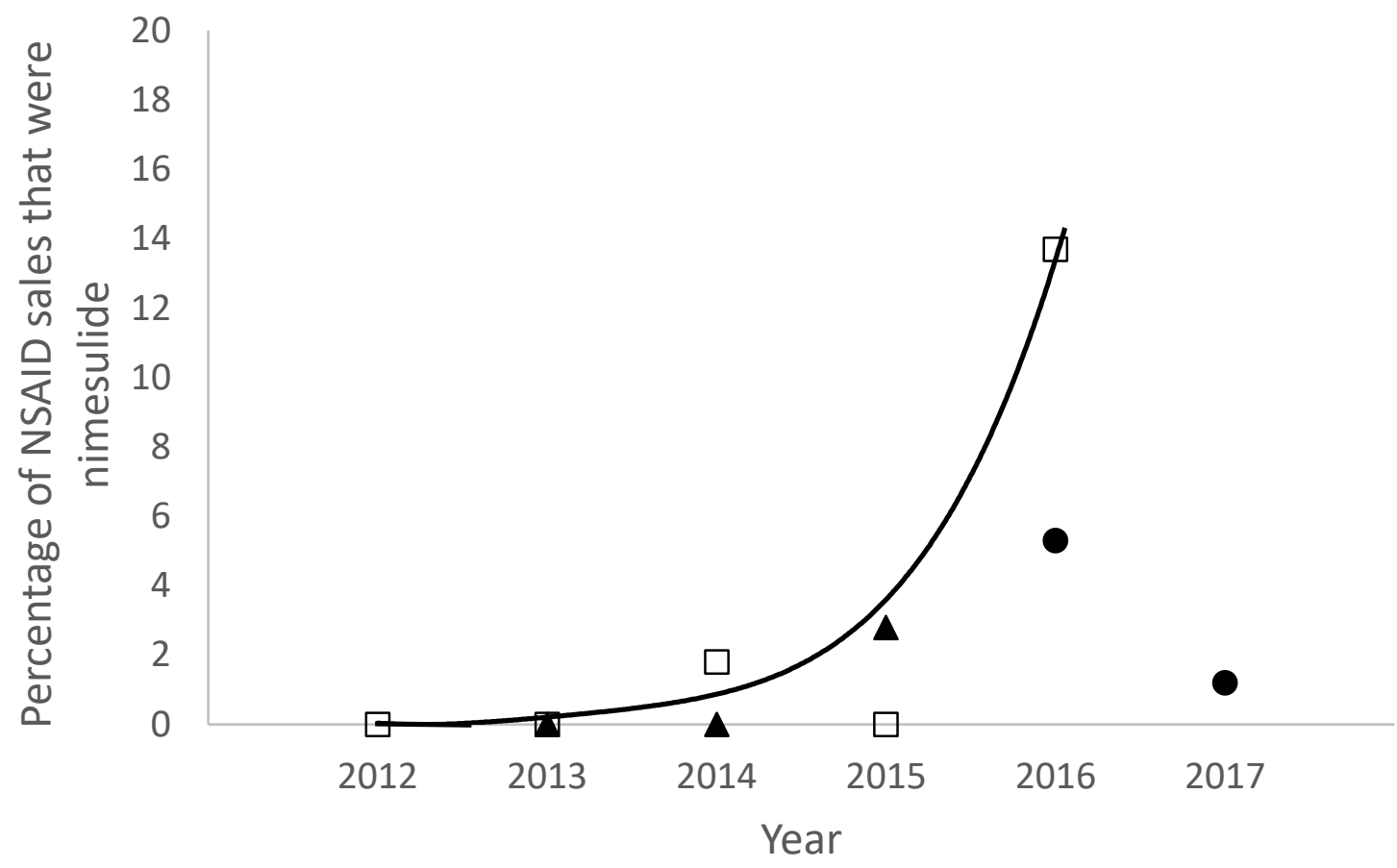

Figure 2c 


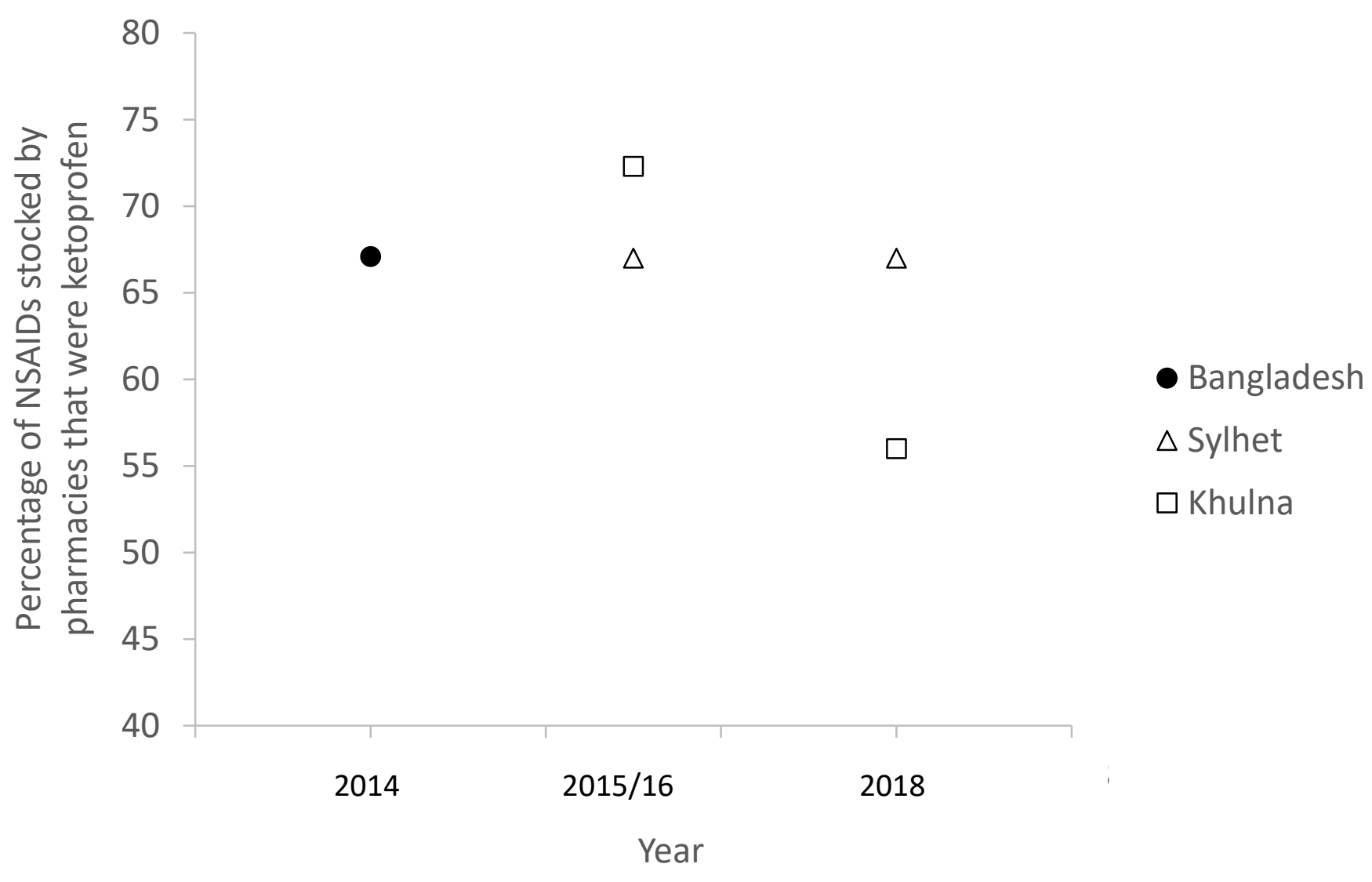

Figure 3a. 


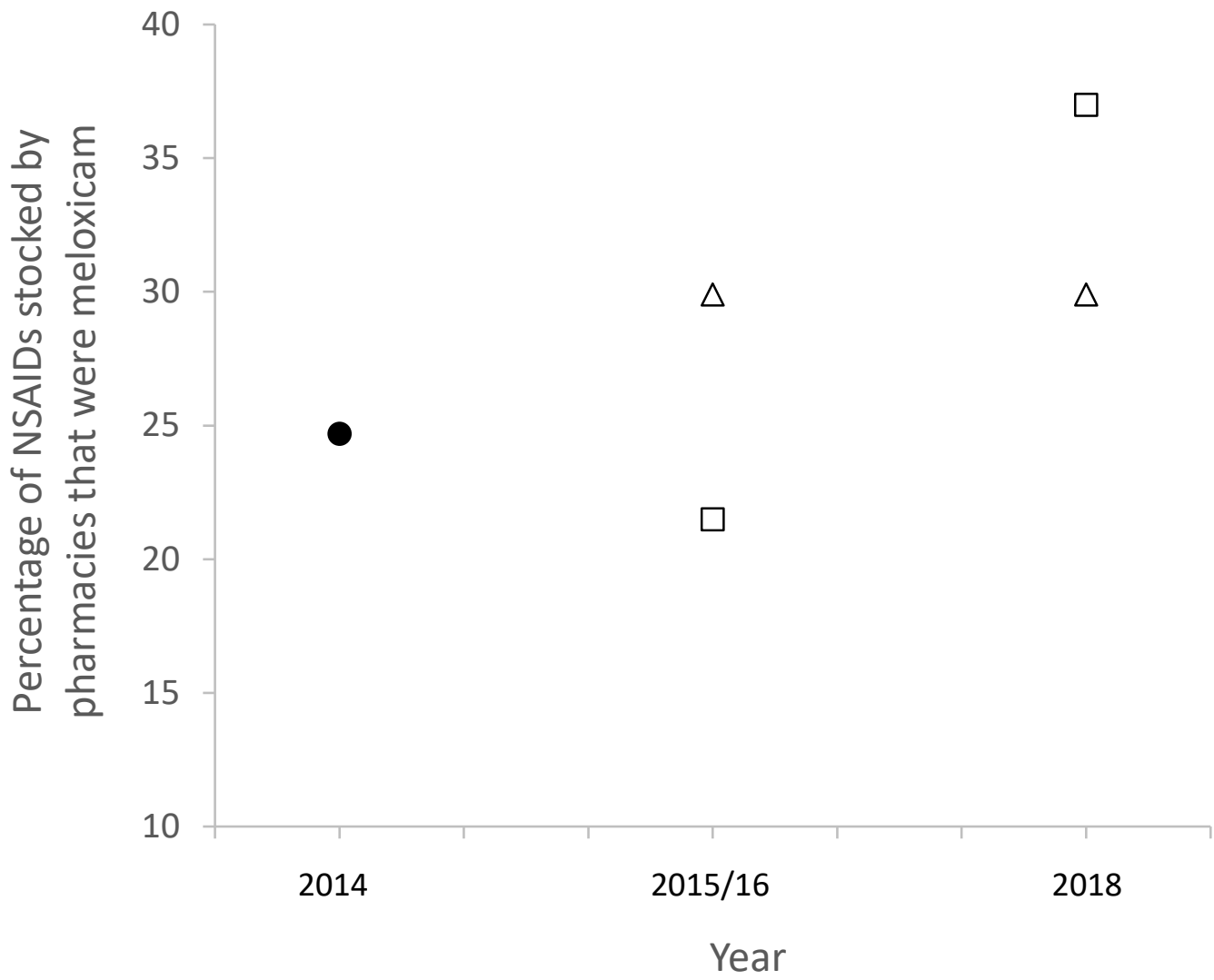

- Bangladesh

$\triangle$ Sylhet

$\square$ Khulna

Figure 3b. 


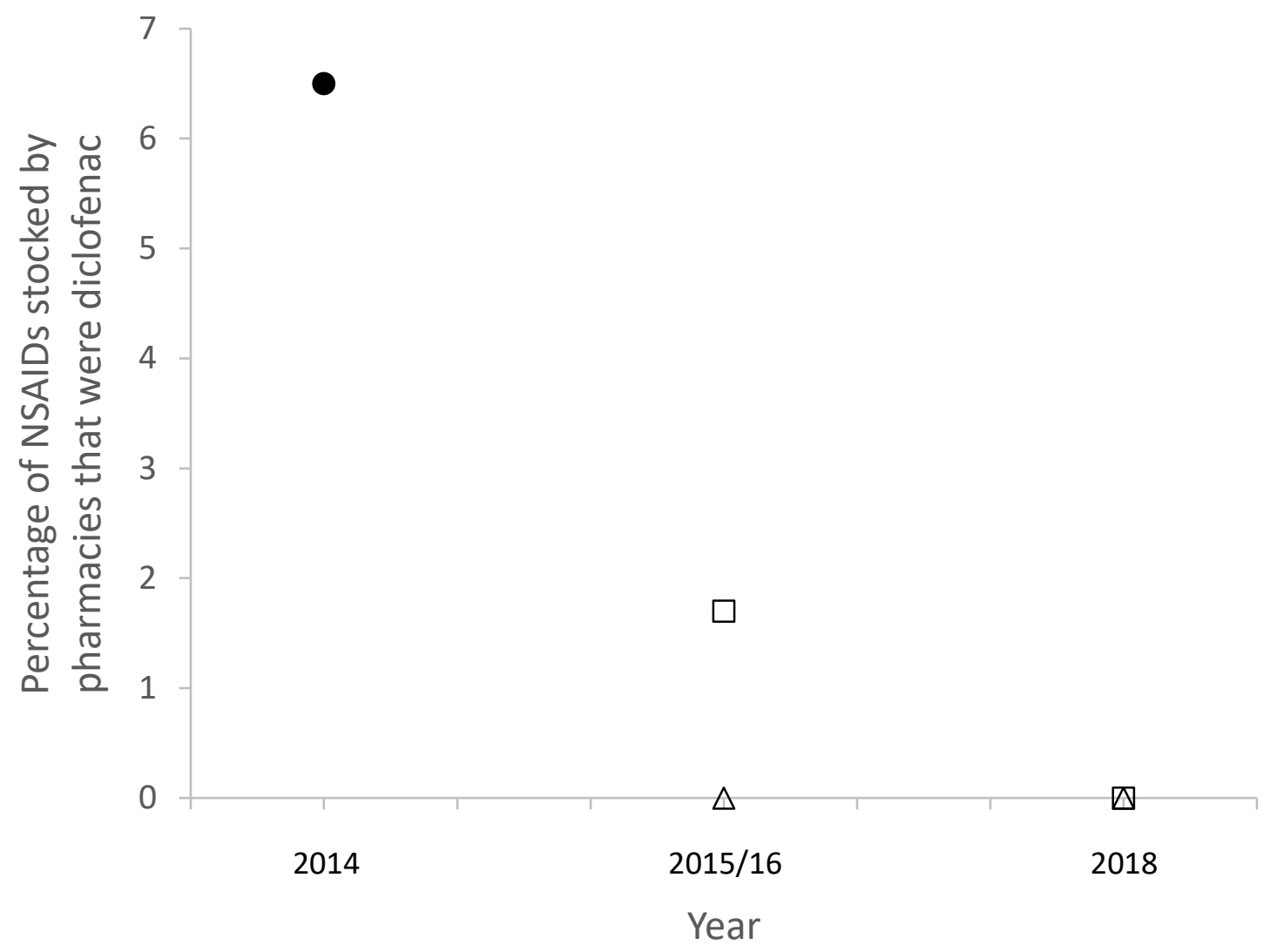

- Bangladesh $\triangle$ Sylhet

$\square$ Khulna

Figure 3c. 